\title{
STRATEGI PEMBINAAN AKHLAK SANTRI DI PONDOK PESANTREN INTERNASIONAL DEA MALELA
}

\author{
Sriyatun ${ }^{1}$, Arif Budi Witarto², Mega Trishuta Pathiassana ${ }^{3}$, Moh Kodri $^{4}$
}

${ }^{1 * 2}$ Pascasarjana Manajemen Inovasi Universitas Teknologi Sumbawa

${ }^{3^{*}}$ Fakultas Teknologi Pertanian Universitas Teknologi Sumbawa

*Corresponding Author email: arifwitarto@gmail.com, mega.trishuta@uts.ac.id,

\begin{abstract}
Abstrak
Diterima:

Bulan Juni 2020

\section{Diterbitkan:}

Bulan Juli 2020

Keyword :

Akhlak,

Komunikasi, membina, Pola, Pesantren

Pesantren merupakan salah satu jenis lembaga pendidikan yang berbasis keagamaan. Pondok Pesantren Internasional Dea Malela merupakan salah satu sekolah Islam yang modern dan seluruh santrinya menetap di pondok pesantren boarding school. tujuan dari penelitian ini adalah untuk mengetahui strategi pembinaan yang diterapkan oleh Ustadz terhadap santri di Pesantren Internasional Dea Malela sehingga bisa menjadi acuan untuk pondok pesantren lain dalam pembinaan akhlak santri menjadi lebih baik, dan untuk mengetahui faktor pendukung dan penghambat dalam strategi pembinaan antara ustadz dan santri dalam menanamkan nilai-nilai akhlak. Metode penelitian yang digunakan dalam penelitian ini adalah metode kualitatif yang merupakan metode-metode untuk mengeksplorasi dan memahami makna oleh sejumlah individu atau sekelompok orang yang berasal dari masalah sosial atau kemanusiaan. Hasil dari penelitian ini adalah Strategi pembinaan yang dilakukan di Pondok Pesantren Internasional Dea Malela yaitu dengan menerapkan kedisiplinan, keteladanan, kesederhanaan, pembiasaan dan memperbanyak kegiatankegiatan yang bisa memaksimalkan potensi dari setiap santri. Untuk bidang kepesantrenan PPM Dea Malela memiliki program-program wajib seperti Qiyamul-Lail, One Day One Verse, Literasi, Sholat Dhuha, Muwajjah (belajar malam), Ma'tsuroh (berdoa bersama sebelum tidur), pengabsenan, belajar kosakata Bahasa Arab dan Inggris, Baca al-Qur'an, Halaqoh bersama Wali Asuh, pelatihan Public Speaking atau pidato.
\end{abstract}

\section{PENDAHULUAN}

Pendidikan di pondok pesantren pada umumnya mengajarkan ilmu-ilmu tentang agama secara mendalam dan bagaimana ilmu agama yang dipelajarai bisa diaplikasikan dalam kehidupan sehari-hari. Pondok Pesantran sebagai lembaga pendidikan mempunyai tujuan yang tidak berbeda dengan pendidikan agama Islam lainnya yakni sebagai lembaga pendidikan untuk pembentukan akhlak yang baik, sebagai lembaga dakwah dan lembaga kemasyarakatan.

Pondok pesantren di Indonesia jumlahnya sangat banyak yang tersebar diseluruh Indonesia. Berdasarkan data statistik Ditjen kelembagaan Islam departemen Agama Republik Indonesia pada tahun 2016 ada 28.194 pesantren dan selalu mengalami peningkatan dari tahun ke tahun. Mengingat pentingnya akhlak bagi suatu bangsa, sehingga perlu adanya keseriusan pemerintah dalam pembinaan akhlak bagi peserta didik yang dimana mereka masih dalam masa pembentukan karakter, karena sifat karakter yang melekat pada manusia berkembang secara dinamis (Sutiyono, \& Prasetyo, D,. 2020) dan peserta didik saat ini merupakan calon pemimpin bangsa dimasa mendatang. Oleh karena itu, pendidikan karakter peserta didik sangat ditekankan oleh pemerintahan sekarang ini.

Akhlak sebagai suatu Ilmu yang merupakan salah satu bahasan pokok dan substansial dalam Islam, yang jika kita kaji lebih dalam tidak hanya terbatas pada tingkah laku manusia dari segi fisik, tetapi juga berkaitan dengan aspek batin dan kebahagiaan hidup. Kejiwaan menyangkut dimensi penting yang meliputi persoalan kebaikan dan keburukan manusia di dunia dan kehidupan di akhirat, bangsa yang kokoh adalah bangsa yang memiliki akhlak yang baik. Sebaliknya, bangsa bisa runtuh ketika akhlak manusia di dalamnya rusak, sehingga sangat diperlukan untuk mendidik akhlak remaja yang dimiliki oleh bangsa.

Masa remaja merupakan masa peralihan antara masa kanak-kanak ke masa dewasa dimana individu remaja mengalami masa penyesuaian diri dengan lingkungan di sekitarnya khususnya di 
tatanan norma, nilai, adat dan etika yang berlaku dimasyarakat. Terjadi perubahan secara fisik, biologis, mental dan emosional serta sosial.remaja diartikan sebagai masa perkembangan antara masa anak dan masa dewasa yang mencakup perubahan biologis, intelektual dan emosional. Secara lebih rinci, menurut Haditono (Jannah, 2016) masa remaja dibagi menjadi empat fase, yaitu masa pra remaja 10-12 tahun, masa remaja awal 12-15 tahun, masa remaja pertengahan 15-18 tahun, dan masa remaja akhir 18-21 tahun. Proses tumbuh kembang remaja harus mendapat perhatian yang khusus terutama dalam ruang lingkup keluarga atau orang tua, agar tahap perkembangan tersebut dapat terkontrol dengan baik, apabila hal ini tidak terkontrol dengan baik akan menimbulkan kenakalan remaja.

Angka kasus kenakalan remaja meningkat setiap tahunnya, pada tahun 2015 kasus kenakalan remaja mencapai 4.309 kasus, terus meningkat mencapai 4.622 kasus pada tahun 2016, dan pada tahun 2017 mencapai 4.579 kasus dan terjadi peningkatan kembali di sepanjang 2018 sebanyak 4.885 kasus. Berdasarkan data statistik diatas, kasus kenakalan remaja terdiri dari berbagai jenis kasus, seperti kasus perkelahian, menghabiskan waktu untuk hura-hura, minum-minuman keras, narkoba, berjudi, melawan guru, melawan orangtua bahkan sampai kasus pemerkosaan dan pembunuhan. Meningkatnya angka kenakalan remaja sangat diperlukan penanganan serius oleh berbagai pihak baik pemerintah maupun masyarakat, karena remaja merupakan faktor penting dalam pembangunan bangsa dan negara. Anak-anak adalah generasi yang akan menjadi penerus pemimpin dimasa yang akan datang dan akan menghadapi tantangan masa depan, sehingga generasi muda memerlukan pembinaan sejak dini untuk mencapai investasi yang baik dan berkesinambungan bagi bangsa dan negara.

Pembinaan generasi muda merupakan usaha yang dilakukan secara efektif untuk memperoleh hasil yang lebih baik. Menurut Simanjuntak (Hayati dkk, 2016) Pembinaan adalah upaya membina dalam dunia pendidikan, baik formal maupun non formal yang dilaksanakan secara sadar, teratur, terarah, terencana dan bertanggung jawab dalam rangka memperkenalkan, menumbuhkan, membantu dan mengembangkan suatu dasar-dasar kepribadian yang seimbang, utuh selaras antara pengetahuan dan keterampilan yang sesuai dengan bakat, kecenderungan dan keinginan serta kemampuan sebagai bekal untuk dimasa yang akan datang. Pembinaan generasi muda yang baik menentukan perkembangan suatu negara yang baik. Pesantren adalah salah satu lembaga pendidikan yang efektif dikarenakan faktor pembinaan dan lingkungan yang mendukung. Pesantren merupakan salah satu jenis lembaga pendidikan yang berbasis keagamaan, Menurut Manfred (Wahyuddin, 2016). Sementara menurrut Effendi (Said, 2011) pesantren dipahami sebagai kampung peradaban.

Kementerian Agama Republik Indonesia mengklasifikasikan pondok pesantren menjadi empat bentuk. Pengklasifikasian ini tertuang dalam Peraturan Menteri Agama Nomor 3 Tahun 1979 tentang Pondok Pesantren, keempat bentuk tersebut ialah (1) Pesantren tipe A adalah pesantren yang seluruh kegiatannya dilaksanakan secara tradisional, santri belajar dan bertempat tinggal di asrama (2) Pesantren tipe $\mathrm{B}$ adalah pesantren yang menyelenggarakan pengajaran secara klasikal (Madrasah), (3) Pesantren tipe $\mathrm{C}$ adalah pesantren yang hanya merupakan asrama, sedangkan santrinya belajar diluar (dimadrasah atau sekolah umum lainnya), (4) Pesantren tipe D adalah pesantren yang menyelenggarakan sistem ponpes sekaligus sistem sekolah dan madrasah. Dalam menjalankan sistemnya, pondok pesantren pada umumnya memerlukan ustadz yang membimbing dan mengajar serta memberi sauri tauladan. Salah satu pesantren yang telah berdiri di Indonesia adalah Pondok Pesantren Internasional Dea Malela.

Berdasarkan uraian di atas, strategi yang digunakan dalam pembinaan akhlak santri adalah salah satu faktor yang bisa menyatukan antara negara dan budaya, sehingga peneliti tertarik melakukan penelitian tentang strategi yang digunakan ustadz dalam membina akhlak santri. Santri yang tidak hanya berasal dari Indonesia termasuk juga santri yang berasal dari berbagai negara yang ada di Pondok peantren Internasional Dea Malela.

\section{LANDASAN TEORI Strategi pembinaan}

Strategi merupakan sesuatu yang direncanakan untuk mencapai sesuatu tujuan jangka panjang dimana Strategi adalah pendekatan secara keseluruhan yang berkaitan dengan pelaksanaan, gagasan, perencanaan, dan eksekusi sebuah aktivitas dalam kurun waktu tertentu.

Pembinaan merupakan suatu proses yang dilakukan untuk merubah tingkah laku secara individu serta membentuk kepribadian sehingga tercapai sesuai yang diharapkan. Pembinaan apabila dilakukan secara efektif dan efisien dan dilakukan secara terus menerus maka akan memperoleh hasil yang lebih baik. Pembinaan adalah proses yang berkesinambungan dan tidak ada pembinaan yang bersifat final.

Akhlak adalah bentuk jamak dari kata khuluk, berasal dari bahasa Arab yang berarti perangai, tingkah laku, atau tabiat. Tiga pakar di bidang akhlak yaitu Ibnu Miskawaih, Al Gazali, dan Ahmad Amin menyatakan bahwa akhlak adalah 
perangai yang melekat pada diri seseorang yang dapat memunculkan perbuatan yang baik tanpa mempertimbangkan pikiran terlebih dahulu. Kata akhlak diartikan sebagai suatu tingkah laku, tetapi tingkah laku tersebut harus dilakukan secara berulang-ulang, tidak cukup hanya sekali melakukan perbuatan baik, atau hanya sewaktuwaktu saja. Seseorang dapat dikatakan berakhlak jika timbul dengan sendirinya didorong oleh motivasi dari dalam diri dan dilakukan tanpa banyak pertimbangan pemikiran apalagi pertimbangan yang sering diulang-ulang, sehingga terkesan sebagai keterpaksaan untuk berbuat. Apabila perbuatan tersebut dilakukan dengan terpaksa bukanlah pencerminan dari akhlak. Dalam Encyclopedia Brittanica akhlak disebut sebagai ilmu akhlak yang mempunyai arti sebagai studi yang sistematik tentang tabiat dari pengertian nilai baik, buruk, seharusnya benar, salah dan sebagainya tentang prinsip umum dan dapat diterapkan terhadap sesuatu, selanjutnya dapat disebut juga sebagai filsafat moral.

Pada dasarnya kenakalan remaja adalah perilaku penyimpangan yang tidak hanya merugikan diri sendiri akan tetapi merugikan orang lain, bangsa, dan negara. oleh karena itu, para remaja harus di fasilitasi dengan lingkungan yang kondusif serta pola pembinaan yang tepat, agar para remaja menjadi generasi penerus sesuai dengan harapan bangsa dan agama.

Strategi pembinaan akhlak santri di pondok pesantren yang dilakukan oleh (sawaty, 2018) menjelaskan strategi dalam pembinaan akhlak santri dilakukan secara terencana, terprogram dan berkelanjutan, penanaman nilai-nilai akhlak yang dilakukan oleh ustadz berjalan dengan efektif dikarenakan pembinaan yang dilakukan melalui strategi yang beragam seperti strategi formal, strategi non formal, strategi alami, strategi keteladanan, strategi ceramah, strategi dengan menceritakan kisah-kisah dan strategi nasehat. Komunikasi interpersonal antara kiai dan santri dalam menanamkan nilai-nilai akhlakul karimah di Pesantren Al-Mustaqim di Jepara yang dilakukan oleh (Muslim \& umam, 2019). Penelitian ini menjelaskan tentang proses pembinaan interperonal yang dilakukan antara kiai dan santri dalam menanamkan nilai-nilai akhlakul karimah di Pondok Pesantren Al-Mustaqim Desa Bugel Kecamatan Kedung Kabupaten Jepara yang terdiri dari pembinaan interpersonal secara tatap muka (direct communication) dan terjadi dalam dua bentuk proses, yakni proses komunikasi interpersonal yang terjadi pada sesi pengajian dengan jenis komunikasi diadik dan komunikasi kelompok kecil serta proses komunikasi interpersonal non pengajian.
Penelitian yang dilakukan oleh (Rahmawati, 2014) tentang metode-metode pembinaan akhlak di Pondok Modern Darussalam Gontor Putri IV Desa Lamomea Kecamatan Konda Kabupaten Konawe Selatan Tahun 2014.Ialah (1) Ustadzah atau guru harus memberikan contoh serta keteladanan yang baik (uswatun hasanah) dengan berlandaskan Al-Quran dan Sunnah dalam hal beribadah ataupun dalam perilaku di kehidupan sehari-hari, yang (2) Latihan dan Pembiasaan, santri di didik dan dibiasakan untuk disiplin dalam mengikuti kegiatan-kegiatan yang bersifat amaliah, seperti shalat berjamaah, bersikap sopan santun kepada kiai dan ustadzah serta saling menghargai dalam bergaul dengan sesama santri, yang (3) mengambil pelajaran (ibrah) disetiap peristiwa yang terjadi di dalam kehidupan, agar senantiasa berfikir lebih baik lagi kedepannya dan mendorong semangat belajar dan semangat beribadah sesuai dengan tuntunan agama. dan yang ke (4) Nasehat (mauidzah) santri harus senantiasa ikhlas menerima nasehat dari Kiai ataupun guru dalam hal kebaikan, agar dalam beribadah santri-santri tersebut bisa lebih meningkatkan kembali amal-amal kebaikannya dalam mendekatkan diri kepada Allah SWT dan selalu berjamaah dalam melakukan kebaikan dan ibadah dalam kehidupan di dunia ini. Dalam pembinaan akhlak santriwati pada Pondok Modern Gontor Putri IV, ada beberapa metode yang digunnakan dalam kurikulum pendidikannya yaitu, metode latihan dan pembiasaan, metode kedisiplinan, uswatun hasanah, Metode ceramah (Ibrah dan Muadziah), dalam pembinan akhlak santriwati di Pondok Modern Gontor Putri IV, kenyataannya mengadapi kendala-kendala. Faktorfaktor yang merupakan penghambat dan mempengaruhi proses pembinaan akhlak itu berdasarkan temuan peneliti adalah kurangnya pemahaman orang tua/wali santri terhadap pendidikan di Pondok Pesantren, termasuk didalamnya tidak memahami visi, misi dan strategi pendidikan di Pondok Pesantren, adanya pengaruh negatif dari perkembangan teknologi informasi dan media massa turut menghambat proses pembinaan akhlak. Gaya hidup atau life style yang merasuki anak remaja melalui media massa dan media elektronik banyak yang bertentangan dengan nilainilai akhlakul karimah menurut ajaran Islam. Disamping faktor-faktor penghambat tersebut, terdapat pula faktor-faktor yang memberikan pengaruh positif terhadap pembinaan akhlak santri yaitu, adanya kerja sama yang baik antar komponen di dalam lembaga Pondok Pesantren Modern Gontor Putri IV, adanya kerjasama yang baik antara Orang tua atau wali santri dengan Pondok Modern Gontor Putri IV.

Teori yang mendukung pendekatan masalah 
Akhlak merupakah hal yang tidak bias dipisahkan dari kehidupan manusia. Banyak faktor yang mempengaruhi akhlak seseorang diantaranya faktor internal yang meliputi insting dari individu dan lingkungan keluarga, sedangkan faktor eksternal meliputi pergaulan, media elektronik dan media massa hingga lingkungan disekitar yang dapat mempengaruhi akhlak seseorang. Hal ini mengakibatkan lingkungan pesantren sangat menunjang dalam pembentukan karakter sejak dini, dikarenakan lingkungan pesantren telah disesuaikan dengan pedoman keagamaan dan rutinitas yang dapat mempengaruhi akhlak setiap santrinya. Hal ini selaras dengan yang dikatakan (Krisnatuti, dkk, 2011) kehidupan di pesantren menuntut santri untuk mengikuti banyak kegiatan dan rutinitas sesuai aturan dengan baik. Hal ini sangat mempengaruhi pembentukan karakter santri dan sangat efektif untuk merubah akhlak seorang santri.

Santri adalah mereka yang dengan taat melaksanakan perintah agamanya, yaitu Islam (Izzah, 2011). Pola pembinaan yang ditempuh kebanyakan pesantren yang ada di Indonesia ialah berdasarkan ajaran agama Islam. Pola yang dimaksudkan sebelumnya dirancang sesuai dengan kebutuhan setiap pesantren, pola pembinaan yang dirancang meliputi pembinaan formal yakni kegiatan pendidikan yang selaras denga peraturan pemerintah dan tidak melanggar ketetapanketetapan yang berlaku dan pembinaan non formal yakni kegiatan yang dirancang khusus dan hanya dilakukan di lingkungan pesantren. Menurut (Rasyida, 2018) Pola pembinaan yang sering diterapkan di pesantren ialah pembinaan kepribadian islam yang meliputi aqidah, pembinaan keimanan, pembinaan akhlak hingga pola bermasyarakat. Pola pembinaan yang bermodelkan perintah, larangan, tabligh (motivasi), qudwah (teladan), hingga model transfer pemikiran melalui komunikasi dua arah yang dilakukan antara ustadz dengan santri.

Dalam kamus besar bahasa indonesia dijelaskan bahwa pembinaan adalah sebagai proses, perbuatan, atau cara membina. Arti dapat ditelusuri dari kata dasar bina yang mendapat prefiks pen-an sufiks-an sehingga menjadi proses perbuatan, atau cara. Sementara menurut (Poerwadarminta, 1984: 141). Pembinaan diartikan pembangunan dan pembawaan. Kedua pendapat ini pada hakikatnya tidak berbeda, hanya arti pembinaan itu sendiri yang bersifat luas, tergantung presepsi yang menafsirkannya. Dengan kata lain, pembinaan berarti proses, perbuatan, cara membina juga berarti dengan pembangunan atau pembawaan. Pembinaan dapat juga berarti proses melakukan kegiatan membina atau membangun sesuatu, contohnya seperti membina generasi bangsa. Akhlak dapat diartikan dengan kumpulan kaidah untuk menempuh jalan yang baik, jalan yang sesuai dengan tuntunan Al-Qur'an dan Hadits(Anwar, 2010).

\section{MATODE PENELITIAN}

\section{Rancangan penelitian}

Penelitian ini menggunakan penelitian kualitatif yang merupakan metode-metode untuk mengeksplorasi dan memahami makna oleh sejumlah individu atau sekelompok orang yang berasal dari masalah sosial atau kemanusiaan. Hal ini sesuai dengan penelitian yang dilakukan dalam rangka melihat Strategi dalam membina akhlak di kabupaten Sumbawa.

Fokus penelitian lebih memfokuskan pada strategi pembinaan akhlak yang dilakukan oleh Ustadz dalam membina akhlak para santri dan santriwati di Pesantren Dea Malela. Penelitian ini dilakukan selama kurang lebih tujuh bulan terhitung dari bulan januari 2020 sampai juli 2020 dan peneliti memilih lokasi penelitian di Pondok Pesantren Modern Internasional Dea Malela.

Peneliti memfokuskan penelitian dalam mencari sumber data kepada informan yaitu pengasuh, Ustadz (Pembina), organisasi santri, dan juga Santri. Dengan tujuan agar mendapatkan informasi tentang proses membina akhlak di Pondok Pesantren Dea Malela, adapun sumber data yang diambil dari santri yakni ingin mendapatkan informasi tentang hasil pembinaan akhlak yang di terapkan para Ustadz di Pondok Pesantren Dea Malela.

Penulis menggunakan dua sumber data untuk menunjang peneliti ini, yaitu sumber data primer dan sumber data sekunder. Sumber data primer adalah data langsung diperoleh dari lapangan (Nasution, 2006). Adapun sumber-sumber data primer dalam penelitian ini diperoleh melalui wawancara dan pengamatan terhadap ustadz, staff, santri, Pondok Pesantren Internasional Dea Malela. Sumber data sekunder adalah sumber data yang diperoleh dari sumber kedua atau sumber sekunder dari data yang kita butuhkan (Bungin, 2013). Data sekunder merupakan data yang dikumpulkan dan berasal dari hasil kegiatan pengumpulan data pihak lain. Sehingga peneliti juga menggunakan sumber data dokumen yang meliputi: sejarah berdirinya, visi, misi, tujuan, serta struktur pengurus Pondok Pesantren Internasional Dea Malela, dan lain sebagaianya.

Prosedur pengumpulan data dalam penelitian kualitatif ini melibatkan tiga jenis strategi yaitu Observasi kualitatif yaitu peneliti langsung turun ke lapangan untuk mengamati perilaku dan aktivitas individu-individu di lokasi penelitian yaitu di 
Pondok Pesantren International Dea Malela. Dalam hal ini peneliti merekam/mencatat baik dengan cara terstruktur maupun semistruktur (misalnya, dengan mengajukan sejumlah pertanyaan yang dirancang untuk memudahkan peneliti dalam mengumpulkan data yang dibutuhkan), Wawancara Kualitatif yaitu peneliti melakukan face to face interview (wawancara berhadap-hadapan) dengan informan yang dalam hal ini adalah santri, Ustadz, dan Pembina di Pondok Pesantren Dea Malela, atau mewawancarai mereka dengan telepon. Wawancara seperti ini akan dilakukan melalui pertanyaan umum dan terbuka untuk menggali informasi lebih dalam, dan Dokumentasi Kualitatif yaitu berupa dokumen publik (misalnya, koran, makalah, laporan, dll) untuk menelusuri dokumen-dokumen yang terkait dengan penelitian untuk menunjang penelitian yang peneliti teliti di Pondok Pesantren Dea Malela.

Analisis data merupakan proses berkelanjutan yang membutuhkan refleksi terus menerus terhadap data, mengajukan pertanyaan-pertanyaan analisis, dan menulis catatan singkat selama penelitian. Teknik analisis data yang peneliti gunakan dalam penelitian ini antara lain Mengolah dan mempersiapkan data, Reduksi Data, Penyajian Data, dan Verifikasi data.

\section{HASIL DAN PEMBAHASAN}

\section{Gambaran umum pesantren Dea Malela}

Sejarah singkat berdirinya Pondok Pesantren Modern Dea Malela yang didapatkan dari hasil wawancara kepada Pimpinan Pondok Pesantren Dea Malela yang diwakili oleh Ustadz Solahudin yang merupakan utusan dari Pimpinan Pondok Pesantren Modern Dea Malela. Pondok pesantren ini terletak di Dusun Pemangon Brang rea, Kecamatan Lenangguar, Kabupaten Sumbawa, Provinsi Nusa Tenggara Barat. Pondok Pesantren Modern Dea Malela berdiri sejak bulan Februari 2016 dan diresmikan oleh Anis Baswedan yang saat itu menjabat sebagai Mentri Pendidikan dan Kebudayaan. Pesantren Modern Dea Malela berada di bawah naungan Yayasan Pendidikan dan Kebudayaan Dea Malela (YPKDM) yang didirikan oleh Prof. Dr. M. Din Syamsuddin dengan tujuan memberikan banyak kontribusi kemajuan pendidikan dan kebudayaan Indonesia, berdirinya pondok pesantren ini di dukung penuh oleh Pemerintah Kabupatan Sumbawa beserta seluruh masyarakat Sumbawa, sebagai bentuk dukungannya sebidang tanah diwakafkan seluas $30.764 \mathrm{~m}^{2}(3,08$ $\mathrm{Ha})$.

Pondok Pesantren Modern Dea Malela didirikan oleh Prof. Dr. Din Syamsuddin sebagai pembina yayasan. Pondok Pesantren Dea Malela memiliki tenaga pengajar yang berjumlah 43 orang pengajar, yang keseluruhan tenaga pengajar tersebut menetap di pesantren, dan mempunyai peserta didik (Santri) yang berjumlah 299 orang yang terdiri dari santri ikhwan (laki-laki) yang berjumlah 149 dan akhwat (perempuan) berjumlah 150 orang yang terdiri dari tingkat SMP dan SMA, 50 diantaranya merupakan santri dan santriwati yang berasal dari berbagai negara seperti Timor Leste, Malaysia, Thailand, Kamboja, Filipina, dan Rusia. Dalam membina santrinya yang berasal dari luar negri, Pondok Pesantren Dea Malela terlebih dahulu memberikan pengajaran bahasa Indonesia secara intensif selama enam bulan dengan membuat program khusus yaitu Bahasa Indonesia Untuk Penutur Asing (BIPA), maksud dan tujuan program tersebut adalah agar santri yang berasal dari negara lain bisa mengikuti dan memahami pembelajaran di kelas formal ataupun ketika berinteraksi dengan teman-temannya yang berasal dari Indonesia.

Pondok pesantren sebagai Lembaga Pendidikan salah satu alternatif yang berfungsi sebagai penyokong suksesnya pendidikan di Indonesia. Diperlukan keseriusan untuk mengelolanya. Sebagai dasar dari kegiatan tersebut, sebuah lembaga dituntut memiliki kejalasan tantang visi misinya. Visi dan misi Pondok Pesantren Modern Dea Malela adalah sebagai berikut:

\section{Visi}

1. SMP dan SMA Pondok Pesantren Internasional Dea Malela sebagai lembaga pendidikan berkemajuan dan berkeunggulan baik pada taraf nasional maupun internasional.

2. Lulusan SMP dan SMA Pondok Internaional Dea Malela sebagai sumber daya insani yang memiliki keimanan, keilmuan, kepribadian, dan memiliki tekad untuk mengembangkan diri dengan prestasi.

\section{Misi}

1. Menyelenggarakan proses belajar mengajar yang tersistematis, terarah, terstruktur, untuk berdaya guna dan berhasil guna.

2. Menyelenggarakan pendidikan nilai dan kepribadian dalam siklus waktu yang padat dan berisi.

3. Menciptakan suasana pendidikan yang menggembirakan dalam semangat kasih sayang dan kekeluargaan.

Program kegiatan pondok pesantren moderen Dea Malela menyelenggarakan kegiatan pendidikan formal seperti jenjang sekolah menengah Pertama (SMP) dan sekolah menengah atas (SMA), untuk bidang kepesantrenan PPM Dea Malela memiliki program-program wajib seperti Qiyamul-Lail, One Day One Verse, Literasi, Sholat Dhuha, Muwajjah (belajar malam), Ma'tsuroh (berdoa bersama sebelum tidur), pengabsenan, 
belajar kosakata Bahasa Arab dan Inggris, Baca alQur'an, Halaqoh bersama Wali Asuh, pelatihan Public Speaking atau pidato.

Program satu hari satu ayat atau One Day One Verse adalah program pembinaan akhlak yang menjadi rutinitas sehari-hari di Pondok Pesantren Modern Dea Malela yang di mana setiap harinya setelah melaksanakan solat subuh tepatnya pukul 05.00-06.00 program ini dimulai. Seorang ustadz yang biasa di kenal dengan sebutan wali asuh, bertanggung jawab atas amanah yang diberikan yaitu memegang delapan orang santri setiap kelompoknya, di dalam program tersebut wali asuh (ustadz) memberikan satu ayat yang berkaitan dengan akhlak, akidah, dan ibadah, setelah ayat tersebut dihafal lalu di kaji apa maksud ayat tersebut selain itu juga pembetulan bacaan Al-Quran terdapat di dalamnya seperti makhorijulhuruf tempat keluar huruf dan tajwid yang dihafal oleh santri ketika penyetoran hafalan tujuan diadakannya program ini adalah agar santri bisa menerapkan yang dipelajari dalam kehidupan sehari-hari.

Pondok Pesantren Dea Malela memiliki program pemberian kosakata bahasa arab dan bahasa inggris yang dilaksanakan secara rutin kecuali hari rabu dan minggu karena di isi dengan program muhadatsah, dalam prakteknya ustadz memberikan lima kosakata yang ditulis di papan tulis yang wajib di tulis oleh seluruh santri, setelah selesai pemberian kosakata dan santri telah selesai semua menulis di papan tulis, kemudian ustadz membaca kosakata tersebut dan santri mengulangi perkataan yang dikatakan oleh ustadz, selanjutnya santri wajib menghafal kosakata yang diberikan pada hari itu, kemudian disetorkan kepada ustadz satu persatu oleh santri yang sudah hafal kosa katanya tersebut, dan selanjutnya ustadz menandai dengan paraf pada setiap buku santri yang sudah menyetorkan dan menulis kosakata yang diberikan ustadz, bagi yang sudah menghafal dengan benar dan tepat diperbolehkan meninggalkan pembelajaran untuk bersiap-siap melanjutkan program berikutnya.

Program wajib selanjutnya yaitu program literasi membaca buku di pagi hari sebelum masuk sekolah. Masing-masing santri masuk ke dalam perpustakaan untuk membaca buku setelah solat dhuha di pagi hari tepatnya pukul 07.00-07.30 dalam pelaksanaannya seluruh santri diabsen dan diawasi oleh ustadz yang bertugas. Pembinaan akhlak selanjutnya setelah pembelajaran sekolah usai para santri bersiap untuk melaksanakan sholat zuhur berjamaah di masjid yang dikordinir oleh Organisasi Santri Dea Malela (OSDM) bagian keamanan dan bagian ta'lim atau peribadatan. Selanjutnya seluruh santri duduk dengan rapih dengan membaca Al-
Quran bershaf untuk menunggu adzan dzuhur dikumandangkan.

Di Pondok Pesantren Dea Malela juga di programkan muhadatsah atau latihan percakapan, teknis program tersebut dilapangan terbuka, santri yang berdiri berbanjar dan berpasang-pasangan dua orang, di dalam program tersebut santri wajib berbicara memakai bahasa Arab dan Inggris berpatokan dengan jadwal yang diberikan pengurus bahasa pada minggu pertama bahasa Arab atau bahasa Inggris, dan program ini diawasi oleh ustadz yang keliling memantau santri-santri menegur apabila ada yang diam dan membenarkan santri apabila ada yang salah dalam pengucapan, program ini di laksanakan pada setiap hari minggu setelah melaksanakan sholat subuh berjamaah.

Faktor pendukung dalam pembinaan akhlak yang pertama adalah Pendekatan humanis, pendekatan yang dilakukan dalam pembinaan akhlak di Pondok Pesantren Dea Malela artinya memanusiakan manusia, tidak ada hukuman fisik sehingga santri lebih terbuka dalam menyampaikan permasalahan apapun yang terjadi yang dirasakan di Pondok Pesantren Dea Malela. Selanjutnya keaktifan organisasi yang baik membantu dalam menjalankan program-program yang sudah ditetapkan dalam pembinaan akhlak di Pondok Pesantren Dea Malela, organisasi tersebut dilantik secara resmi oleh pimpinan pondok pesantren yang selanjutnya menjalankan program-program yang sudah ada sesuai bagiannya masing-masing. Hal ini berbanding lurus dengan hasil penelitian yang dilakukan, hasil analisis pada penelitian ini menunjukkan data sebagai berikut.

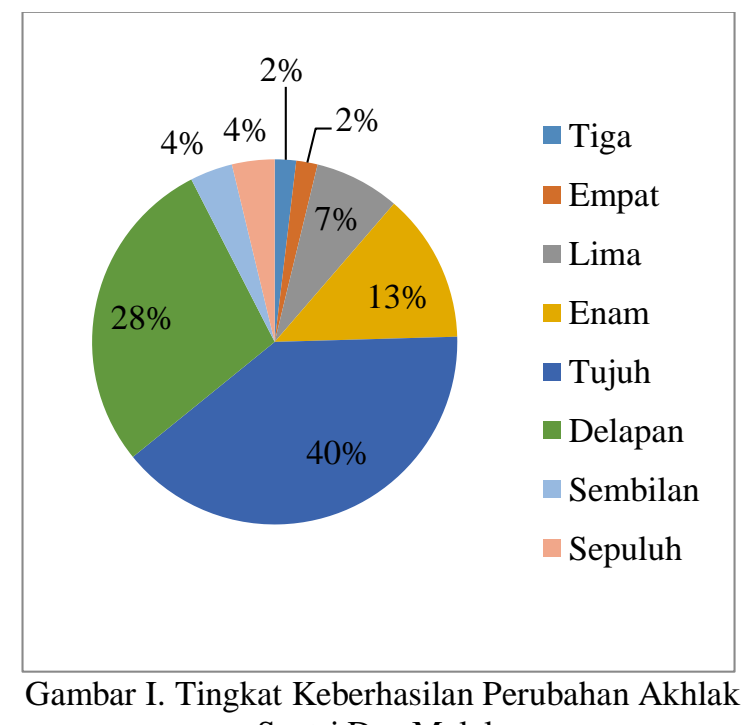

Santri Dea Malela

Dari hasil analisis kuesioner yang disebarkan, penilaian perubahan akhlak santri di pesantren Dea Malela dengan rentan nilai 1 sampai dengan 10 
menghasilkan data sebesar $40 \%$ santri memberikan nilai 7 terhadap perubahan akhlak dari santri tersebut, sebanyak $28 \%$ memberikan nilai 8 untuk perubahan akhlaknya, sekitar $13 \%$ santri memberikan nilai 6 terhadap perubahan akhlaknya, sekitar 7\% santri memberikan nilai 5, sekitar $4 \%$ santri memberikan nilai 9 dan 10, dan sekitar $2 \%$ santri menilai perubahan akhlaknya dengan nila 3 dan 4. Sehingga perubahan akhlak santri yang ada di Pesantren Dea Malela cukup signifikan.

Dalam pembinaan akhlak yang dilakukan, banyak faktor yang mempengaruhi perubahan akhlak yang dimiliki oleh setiap santri, diantaranya Faktor perilaku santri menjadi hambatan dalam pembinaan akhlak di Pondok Pesantren Dea Malela seperti yang sudah disampaikan oleh ustadz Solahudin hasil dari wawancara yang dilakukan, ada saja santri ketika mengikuti program pembinaan akhlak yang tidak serius mendengarkan dan bercanda dengan teman disebelahnya, sehingga hukuman yang pertama yang diberikan ustadz kepada santri yang bersangkutan adalah dengan mengumumkan namanya dihadapan seluruh santri setelah sola isya berjamaah, pembinaan hukuman seperti ini dilakukan agar yang melanggar merasa malu dan tidak ingin melakukan pelanggaran yang sama kembali yang selanjutnya akan menjadi contoh bagi santri-santri yang lainnya agar tidak melakukan hal yang serupa.

Penghambat yang kedua adalah sifat santri yang jail dengan teman-temannya, ketika ustadz Ponpes dea malela menghadapi persoalan seperti itu solusinya adalah ustadz melakukan pembinaan dengan memanggilnya secara personal dan di tanya baik-baik kenapa kamu melakukan ini? Ustadz di pesantren Dea Malela memakai pendekatan humanis, kemudian selanjutnya ustadz di Pondok Pesantren Dea malela juga mencari solusi bagaimana solusinya agar anak tersebut tidak melakukan pelanggaran yang sama, ustadz dalam membina berdiskusi mencari solusi bersama serta mencari jalan yang terbaik seperti orang tua dengan anaknya biasanya hukuman untuk pelanggaran yang menjaili barang temannya adalah hafalan Al-Quran atau setoran kosakata bahasa arab atau bahasa inggris, selanjutnya apabila santri tersebut sudah dilakukan pemanggilan pertama dan diberikan hukuman hafalan dan hukuman tersebut tidak dilaksanakan dan mengulangi pelanggaran yang sama kedua kalinya, maka ada pemanggilan orang tua ke pondok pesantren untuk memberitahukan pelanggaran-pelanggaran yang dilakukan anaknya sekaligus membuat surat perjanjian antara wali santri dan pesantren yang ditandatangani oleh santri, wali santri dan pengasuh, selanjutnya apabila santri masih melanggar pelanggaran yang sama di kemudian hari ketiga kalinya, maka pembina pesantren yang diwakili pengasuh mengambil tindakan untuk mengembalikan santri yang bersangkutan tersebut kepada kedua orang tuanya.

Hambatan yang ketiga berasal dari ponsel santri tersebut. Sebagaimana yang di tuliskan Bapak Harman seorang tenaga pengajar yang ada di Pondok Pesantren Dea Malela yang menyatakan bahwa ponsel cerdas santri sangat berpengaruh terhadap perubahan akhlak santri tersebut, hal ini berbanding lurus dengan temuan pada penelitian yang dilakukan, yakni sebesar $83 \%$ santri mencantumkan nomor ponsel mereka yang menunjukkan bahwa hampir keseluruhan santri memiliki ponsel yang bisa mempengaruhi akhlak mereka, sehingga menurut bapak Harman seharusnya penggunaan ponsel harus dibatasi di dalam lingkungan pesantren.

\section{PENUTUP \\ Kesimpulan}

Pesantren Dea malela sejauh ini sudah berdiri sekitar 4 tahun dengan berbagai program yang mendukung seperti Qiyamul-Lail, One Day One Verse, Literasi, Sholat Dhuha, Muwajjah (belajar malam), Ma'tsuroh (berdoa bersama sebelum tidur), pengabsenan, belajar kosakata Bahasa Arab dan Inggris, Baca al-Qur'an, Halaqoh bersama Wali Asuh, pelatihan Public Speaking atau pidato.

Dari kegiatan yang telah disusun, keseluruhan santri menyatakan merasakan perubahan akhlak dalam diri mereka, namun setiap santri memiliki nilai perubahan akhlak yang berbeda-beda.

Dari keseluruhan program yang telah disusun, ada berbagai hambatan yang sering ditemui didalam menjalankan program seperti ada saja santri ketika mengikuti program pembinaan akhlak yang tidak serius mendengarkan dan bercanda dengan teman disebelahnya, dan juga sifat santri yang jail dengan teman-temannya, hingga penggunaan ponsel yang tidak dibatasi membawa dampak buruk bagi santri tersebut.

\section{Saran}

Ada beberapa hal yang perlu diperhatikan oleh pihak Pondok Pesantren, diantaranya penambahan sarana dan prasarana hingga membuat peraturan yang membetasi aktivitas santri dengan ponselnya. Selain itu, penyediaan bahan ajar sangat perlu, sehingga santri tidak lagi menjadikan ponsel menjadi alat untuk mencari materi dan angka kecurangan dari santri pun bisa ditekan.

Untuk peneliti selanjutnya bisa memperluas populasi penelitian dengan menggunakan keseluruhan populasi yang ada di pesantren untuk menentukan sampel penelitian yang akan dilakukan.

\section{REFERENSI}


Anwar, R. 2010. Akhlak Tasawuf. Jakarta: Pustaka Setia.

Bungin, B. 2013.Metodologi Penelitian Sosial Dan Ekonomi. Jakarta: Kencana Prenada Media Grup

Hayati, E, Dkk. 2016. Pembinaan Perilaku Sosial Remaja Penghuni Yayasan Islam Media Kasih Kota Banda Aceh. Jurnal Ilmiah Mahasiswa Pendidikan Kewarganegaraan Unsyiah, Vol. 1(1): 192-204.

Izzah, I.Y.U. 2011.Perubahan Pola Hubungan Kiai Dan Santri Pada Masyarakat Muslim Tradisional Pedesaan.Journal Sosiologi Islam.Vol.1(2): 31-48

Jannah, M. 2016. Remaja Dan Tugas-Tugasnya Perkembangan Dalam Islam. Jurnal Psikoislamedia, Vol. 1(1): 243-255.

Kristinatuti, D. Dkk. 2011.Hubungan Antara Kecerdasan Emosi Dengankepatuhan Dan Kemandirian Santri Remaja. Jurnal Ilm.Kel \& Kons. Vol. 4(2):148-155

Muslim, K. \& Umam, K. 2019.Komunikasi Interpersonal Antara Kiai Dan Santri Dalam Menanamkan Nilai-Nilai Akhlakul Karimah Di Pondok PesantrenalMustaqim Bugel. Jurnal An-Nida. Vol. 11(1): 24-38

Nasution.2006. Pendekatan Dalam Proses Belajar Dan Mengajar. Jakarta: Bumi Aksara.
Poerwadarminta. 1995. Kamus Bahasa Indonesia . Jakarta: Balai Pustaka.

Rahmawati. 2014. Metode-Metode Pembinaan Akhlak Di Pondok Pesantren Modern Darussalam Gontor Putri Iv. Jurnal AlIzzah. Vol. 9(1): 155-168.

Rasyida, A. 2018.Pola Pembinaan Kepribadian Islami Siswa Di Pesantren Modern AlBarokah Kec.Dolog Batu Nanggar Kab.Simalungun.Skripsi. Fakultas Ilmu Tarbiyah Dan Keguruan, Universitas Islam Negeri Sumatre Utara.

Said, M. 2011.Strategi Penguatan Sumberdaya Manusia Dalam Penguatan Bangsa. Yogyakata: Graha Ilmu.

Sawaty, I. 2018. Startegi Pembinaan Akhlak Santri Di Pondok Pesantren. Jurnal Al-Muidzhah Vol. 1(1): 33-47.

Sutiyono \& Prasetyo, D. 2020. Strategi Padepokan Karakter Dalam Memperkuat Karakter Berpikir Kritis Pada Warga Negara Muda Abad. Jurnal Pendidikan Karakter. No.1

Wahyuddin. 2016. Fungsi Pendidikan Islamdalam Hidup Dan Kehidupan Manuasia (Manusia Yang Memiliki Fitrah/Potensi Dan Sebagai Makhluk Yang Harus Dididik Dan Mendidik). Jurnal Inspiratif Pendidikan. Vol. 5(2): 399-415 